Agro-Science Journal of Tropical Agriculture Food, Environment and Extension Volume 3 Number 2 June 2002 pp. 33 - 36

ISBN 1119-7455

\title{
EJACULATE CHARACTERISTICS OF THREE GENOTYPES OF LOCAL COCKS IN THE HUMID TROPICS
}

\author{
Machebe, N.S and Ezekwe, A. G \\ Department of Animal Science University of Nigeria, Nsukka
}

\begin{abstract}
Twenty four (24) adult Nigerian local cocks comprising 8 naked-neck, 8 frizzle and 8 normal were subjected to two ejaculations per week for 14 weeks using the massage technique. Ejaculates were subjected to both physical and chemical evaluations. Results showed that naked- neck and frizzle cocks had higher $(P<0.01)$ ejaculate volume, sperm concentration, total sperm, and sperm motility than the normal cocks. Semen colour and total abnormal sperm did not differ significantly $(P>0.05)$ among the three genotypes. There were also no significant differences in most of the chemical parameters among the genotypes. From these results the naked-neck and frizzle cocks appear superior to normal cocks under the humid tropical environment in semen output and quality.
\end{abstract}

Key words: genotypes, semen, cock, naked-neck, frizzle.

\section{INTRODUCTION}

The need to develop adaptable poultry breeds in the tropics demand that all available genetic resource bases must be considered. According to Crawford and Gavora, (1993), there exists a major global thrust on genetic preservation and biodiversity, which is reflected in efforts on development of genome and data bank. Thus, in order to avoid the erosion of the indigenous germ plasm, crossbreeding programmes in rural poultry must consider gene preservation aspects. Obioha (1992) noted that the use of local chicken in commercial poultry does not make any economic sense as a result of the absence of valuable economic traits in the local chicken. Interestingly however, they possess survival traits, which probably are an adaptation to the harsh tropical environment.

Therefore, certain measure of improvement can still be achieved because the Nigeria local chicken population is composed of many advantageous gene complexes or marker genes.
These genetic blueprints could be exploited in the development of locally based meat type or egg type chickens suitable for use in the tropics. Among these genes are the naked-neck and frizzle gene, which according to Ibe (1998), confer some tolerance to heat stress and increase the productive capacity of individuals possessing them. Thus, for production at moderately high ambient temperatures of $30^{\circ} \mathrm{C}$ and above, individuals possessing these genes are expected to maintain their productive potential. Marthur and Horst (1990) have reported that birds possessing naked-neck and frizzle genes are superior to normal birds either singly or in combination for egg number, egg weight and 40 week body weight. Under tropical environment, Merat (1986) found that naked-neck cocks significantly produced ejaculates with higher semen volume and number of spermatozoa than normal cocks. Breeding. soundness evaluation is an important tool used in identifying and selecting sires of 
superior genetic worth. Unfortunately, there is a dearth of information on the semen quality of naked-neck and frizzle cocks in Nigeria. Accordingly, this study was undertaken to evaluate the semen quality of naked-neck, frizzle cocks and to compare these with those of normal cocks. Results of the study will help in determining the suitability of these genotype for use in the improvement programmes for local poultry in Nigeria

\section{MATERIALS AND METHODS}

Three groups of mature local cocks made up of 8 frizzle, 8 normal and 8 naked-neck were purchased from local markets in Enugu state. Their body weights ranged from $1.38 \pm 0.01 \mathrm{~kg}$ to $1.48 \pm 0.01 \mathrm{~kg}$. The previous management background of the cocks was unknown. Phenotypically, the plumage of the naked-neck and frizzle bird differentiates them from the normal cocks. In the naked-neck cock, the zones separating the pterylae or apteria are entirely devoid of feathers. In addition, certain pterylae are substantially reduced, not only in the neck area but also on the breast, thigh and other parts (Merat, 1986). Frizzle birds, on the other hand are characterized by imperfect feathers, and with primary feathers curling outward and forward (Obioha, 1992).

Management of the cocks: Each group of cocks was housed separately in a deep litter and was fed commercial growers ration containing $15 \%$ crude protein ad libitum. Cool drinking water was provided ad libitum. All cocks were dewormed during the two weeks preexperimental period.

Semen collection and evaluation: During a two-week pre-experimental semen collection and evaluation period, cocks were trained for semen collection by the massage technique described by Burrows and Quinn, (1937). This was considered necessary not only for effective semen collection but also to make the cocks familiar with the semen Collector. Ejaculates were collected twice weekly from the cocks for a total period of 14 weeks beginning from April 2003 - July 2003. Reaction time of each cock was recorded with a stopwatch. Ejaculates were subjected to both physical and chemical evaluations. Physical evaluation involved the determination of semen colour, semen volume, progressive sperm motility, sperm concentration, and percentage abnormal sperm as described by Zemjanis (1970). After the physical evaluation, the remaining portion of semen of cocks in each group were pooled and centrifuged at $3000 \mathrm{~g}$ for 10 minutes to obtain the seminal plasma which were stored frozen at $-15^{\circ} \mathrm{C}$ until required for chemical analysis. Total protein in the semen was determined using SP400 UV/VIS spectrophotometer at $750 \mathrm{~nm}$ (Lowry et al., 1951). Chloride content of ejaculates was determined by Volhard method as described by Pearson (1976) while cations contents of ejaculates were analysed by the method of Quinn et al (1966) using the atomic absorption spectrophotometer. One way analysis of variance was employed for data analysis using SPSS (2001).

\section{RESULTS AND DISCUSSION}

A total of 672 samples were collected and analyzed. The physical characteristics of semen of the three genotypes of cocks are presented in Table 1. The mean reaction time for the three genotypes showed that naked-neck cocks were ejaculated at a relatively shorter time than the frizzle and normal cocks $(\mathrm{P}<0.01)$. The color of semen of the cocks did not differ significantly being creamy white in almost all the ejaculates collected. This suggests that normal ejaculates could be obtained from these cocks easily by the massage technique without much difficulty. It has been observed that variations in semen colour may arise partly due to the presence of contaminants (Etches, 1998) or as a result of low sperm concentration. Ejaculate volume, sperm concentration, sperm motility, and total spermatozoa were significantly higher $(\mathrm{P}<0.01)$ in the naked-neck cocks than those of frizzle and normal cocks. 
Machebe, N.S and Ezekwe, A. G

Table 1. Physical characteristics of cock semen

\begin{tabular}{|c|c|c|c|c|}
\hline \multirow[b]{2}{*}{ Parameters } & \multicolumn{3}{|c|}{ Genotypes } & \multirow[b]{2}{*}{ Overall } \\
\hline & Naked-neck & Frizzle & Normal & \\
\hline Reaction time (seconds) & $12.11 \pm 0.47^{b}$ & $14.46 \pm 0.55^{\mathrm{a}}$ & $14.23 \pm 0.59^{\mathrm{a}}$ & $13.60 \pm 0.52^{* *}$ \\
\hline Ejaculate volume (ml) & $0.27 \pm 0.01^{\mathrm{a}}$ & $0.24 \pm 0.01^{b}$ & $0.22 \pm 0.01^{\mathrm{c}}$ & $0.24 \pm 0.01 * *$ \\
\hline $\begin{array}{l}\text { Sperm concentration } \\
\left(\mathrm{x} 10^{9}\right) / \mathrm{ml}\end{array}$ & $2.35 \pm 0.08^{\mathrm{a}}$ & $2.34 \pm 0.07^{\mathrm{a}}$ & $2.01 \pm 0.06^{\mathrm{b}}$ & $2.24 \pm 0.07^{* *}$ \\
\hline Sperm motility (\%) & $72.59 \pm 1.05^{\mathrm{a}}$ & $71.88 \pm 1.07^{\mathrm{ab}}$ & $68.93 \pm 1.19^{b}$ & $71.13 \pm 1.10^{*}$ \\
\hline Total sperm (x 109) & $0.65 \pm 0.03^{\mathrm{a}}$ & $0.58 \pm 0.03^{\mathrm{a}}$ & $0.44 \pm 0.02^{b}$ & $0.56 \pm 0.03 * *$ \\
\hline Abnormal sperm (\%) & $9.98 \pm 0.46$ & $9.46 \pm 0.52$ & $9.59 \pm 0.47$ & $9.68 \pm 0.48^{\mathrm{NS}}$ \\
\hline
\end{tabular}

Table 2. Chemical characteristics of cock semen

\begin{tabular}{lcccl}
\hline \multirow{2}{*}{$\begin{array}{l}\text { Parameters } \\
(\mathbf{m g} / \mathbf{1 0 0 m l})\end{array}$} & Naked-neck & Frizzle & Normal & Overall \\
\hline Total protein & $33.33 \pm 2.28$ & $34.08 \pm 3.96$ & $35.92 \pm 1.18$ & $34.45 \pm 2.47^{\mathrm{NS}}$ \\
Chloride & $3.55 \pm 0.49$ & $3.88 \pm 0.32$ & $3.90 \pm 0.28$ & $3.78 \pm 0.21^{\mathrm{NS}}$ \\
Sodium & $13.67 \pm 1.02$ & $12.74 \pm 1.12$ & $13.57 \pm 1.63$ & $13.33 \pm 0.26^{\mathrm{NS}}$ \\
Potassium & $14.88 \pm 1.04$ & $15.14 \pm 1.67$ & $16.24 \pm 1.11$ & $15.42 \pm 0.73^{\mathrm{NS}}$ \\
Calcium & $2.98 \pm 0.58$ & $3.36 \pm 0.30$ & $3.70 \pm 0.49$ & $3.35 \pm 0.26^{\mathrm{NS}}$ \\
Magnesium & $3.57 \pm 0.21$ & $3.07 \pm 0.33$ & $3.80 \pm 0.19$ & $3.48 \pm 0.15^{\mathrm{NS}}$ \\
\hline
\end{tabular}

NS - Not significant

Breed and genotype differences in these parameters have been reported (Egbunike and Oluyemi, 1979). It has been observed that semen output is a function of testis size, which invariably is dependent on body size (Egbunike and Oluyemi, 1979). Thus, the superiority of the naked-neck cocks over the frizzle and normal cocks in semen volume, sperm concentration and total spermatozoa could be attributed to the relatively larger testis size of the naked-neck cocks used in this study judging by the larger body size of this genotype (Naked) neck, $1.46 \pm 0.01 \mathrm{~kg}$; frizzle, $1.34 \pm 0.02 \mathrm{~kg}$; normal; $1.29 \pm 0.01$ $\mathrm{kg})$.
The percent abnormal spermatozoa did not differ significantly $(\mathrm{P}>0.05)$ among the genotypes. The low percentage sperm abnormality of less than $10 \%$ observed in the semen of the cocks compared favorably with values reported by Nwagu et al (1996) for 2 exotic breeds of cocks reared in Nigeria, but they differed highly from $48 \%$ and $42 \%$ reported by Omeje and Marire (1990) for adult cocks of different genetic background.

Improper handling of ejaculates during processing for microscopy could greatly influence values obtained for sperm abnormality. It is worthy to note that physical characteristics of semen of naked-neck and frizzle cocks obtained in this study conform to 
values reported for normal cock semen (Lake, 1966; Egbunike and Nkanga, 1999). The chemical characteristics of semen of the three genotypes are presented in Table 2. Results revealed non-significant differences $(\mathrm{P}>0.01)$ in the chemical contents of semen of cocks. The protein levels in the semen of the cocks did not differ significantly $(\mathrm{P}>0.05)$. The electrolytes- sodium, potassium, calcium, magnesium and chloride concentrations in the semen of the cocks are within the normal range reported for cock semen (Lake 1966). The stability of the chemical constituents irrespective of genotype may be as a result of the absence of accessory reproductive organs in birds. These accessory organs are the major contributors of electrolytes observed in mammalian ejaculates (Mann and Lutwak Mann, 1981)

\section{CONCLUSION}

From these results, it is concluded that the naked-neck and frizzle cocks are superior to the normal cocks in semen output.

\section{REFERENCES}

Burrows, W.H and Quinn, J.P. 1937. The collection of spermatozoa from the domestics fowl and turkey. Poultry Sci. 16:19-24.

Crawford, R.D and Gavora, J.S. 1993. Gene resources: Globa view of inventory and conservation. Proc. $10^{\text {th }}$ Internal. Symp. on current problems of avian genetics. Nitra, Slovakia, 7-10 June 1993 P131-136.

Egbunike G.N and Oluyemi, A. 1979. Competitive studies of the reproductive capacity of Nigerian and exotic poultry breeds. Nig. J. Anim. Prod. 6:47-57.

Etches, R.J. 1998. Reproductions in Poultry. CAB International Wallingford.

Ibe, S.N. 1998. Improving productive adaptability of the Nigeria local chicken. Proc.
Silver.Anniv. Confr. NSAP/WASAP Abeokuta, March 21-26. 1998.P46-465.

Lake, P.E 1966. Physiology and biochemistry of poultry semen. In: Advances in Reproductive Physiology. Vol. I. Anne Mclaren (ed) Academic press NY.P93123.

Lindner, H.R and Mann T.1960. Relationship between the content of androgenic steroids in the testis and the secretary activity of the seminal vesicle on the bull. J Endocrine 21:341-360

Lowry, O.H., Rosebrough, N.I., Farr, A.C. and Randall, R.J. 1951. Protein measurement with folin phenol reagent. J. Biol. Chem., 193:255-273.

Marthur, P.K and Horst, P.1990. Proc. $4^{\text {th }}$ World congress on genetics applied to livestock production: P65-68.

Merat, P.1986. Potential usefulness of the $\mathrm{Na}$ (Naked Neck) gene in poultry production. World Poultry Sci J Vol.42: No.2 June 1986.P124-141.

Nwagu, B.I, Rekwot, P.I Abubakar, B.Y, Oni, O.O., Adeyinka, I.A., and Egbuedo, U.C. 1996. Semen characteristics of Rhode Island Red and White breeder cocks. Nig .J. Anim.Prod.23 (1): 1-4

Obioha, F.C. 1992. A Guide to Poultry Production in the Tropics. Acena Publishers, Enugu.

Omeje, S.I and Marire, B.N.1990. Evaluation of the semen characteristics of adult cocks of different genetic background Theriogenology 34(6): 1111-1118.

Pearson, D.1976. The chemical Analysis of Foods $7^{\text {th }}$ Ed. Churchill Livingston NY. P402452.

Quinn, P.J., White, I.G. and Wirrick, B.R. 1966. The effect of dilution on the concentration of $\mathrm{Na}^{+}, \mathrm{K}^{+}, \mathrm{Ca}^{2+}$ and $\mathrm{Mg}^{2+}$ in ram and bull semen. J. Reprod. Fertili, 12:131-139. SPSS for Windows. 2001. Standard Version SPSS Inc. London.

Zemjanis, R.1970. Collection and evaluation of semen. In: Diagnostic and Therapeutic Technique in Animal Reproduction. $2^{\text {nd }}$ Ed. Williams and Wilkins Co. Baltimore M.D. P139-156. 